\title{
Work well-being and prosocial behavior in a sample of Brazilian workers
}

Bienestar en el trabajo y comportamiento prosocial en una muestra de trabajadores brasileños

\author{
Laila Leite Carneiro \\ Universidade Federal da Bahia \\ Antônio Virgílio Bittencourt Bastos \\ Universidade Federal da Bahia
}

\begin{abstract}
Prosocial voice is as a proactive and positively oriented verbal behavior that the worker emits with the intent of promoting transformation that benefits the group or organization. Despite being a phenomenon widely studied in other countries, in Brazil there are few researches dedicated to this phenomenon. Supported by the literature gap and driven by the Positive Psychology perspective, the aim of this study was to describe how prosocial voice behaviors (PSV) are manifested in different Brazilian workers. Additionally, we sought to analyze the predictive power of well-being at work on these behaviors. From the application of scales to a sample of 360 Brazilian workers, descriptive, correlation and linear regression analyzes were conducted. Results shows that some occupational variables, as well as individual variables interfere with the frequency of PSV issuance. Besides, the better a worker feels about his work, the more likely he is to engage in PSV behaviors.
\end{abstract}

Keywords: Voice; Work; Well-being; Positive psychology

\section{Resumen}

La voz prosocial es un comportamiento verbal proactivo y positivamente orientado que el trabajador emite con la intención de promover transformaciones que benefician al grupo u organización. A pesar de ser un fenómeno ampliamente estudiado en otros países, en Brasil hay pocas investigaciones dedicadas a este fenómeno. Apoyado por la brecha de la literatura e impulsado por la perspectiva de la Psicología Positiva, el objetivo de este estudio fue describir cómo se manifiestan los comportamientos de voz prosocial (PSV) en diferentes trabajadores brasileños. Además, buscamos analizar el poder predictivo del bienestar en el trabajo sobre estos comportamientos. A partir de la aplicación de escalas a una muestra de 360 trabajadores brasileños, se realizaron análisis descriptivos, de correlación y de regresión lineal. Los resultados muestran que algunas variables ocupacionales, así como variables individuales, interfieren con la frecuencia de emisión de PSV. Adicionalmente, lo mejor que un trabajador se siente acerca de su trabajo, lo más probable que tenga comportamientos de PSV.

Palabras clave: Voz; Trabajo; Bienestar; Psicología Positiva 


\section{INTRODUCTION}

Organizations can be understood as a social construction, the result of interactions between the people who constitute them and, as a rule, communicate in order to create, maintain, and transform their structures (Gorden, 1988). It is not uncommon for organizations to expect their employees to be actively engaged and interested in contributing to building their success, helping them to be able to deliver quality products and/or services to ensure their survival and their competitive edge in the market (Botero \& Van Dyne, 2009; Budd, Gollan \& Wilkinson, 2010; Knoll, Wegge, Unterrainer, Silva \& Jønsson 2016; Morrison, 2011). Worker initiative and proactivity are especially desired in organizational settings where there is greater decentralization of power and horizontalization of hierarchical authority (LePine \& Van Dyne, 2001; Parker, Williams \& Turner, 2006). Organizations sometimes invest in formal mechanisms to encourage active worker participation, such as financial bonuses or other types of rewards, but even if such resources do not exist, these contributions are usually expected to occur spontaneously, as a demonstration of the employee's interest in helping the organization attain levels of excellence.

Collaborative worker behaviors that occur spontaneously, driven by the desire to contribute to the collective construction of a more efficient, effective, and healthy organization, are also known as discretionary or extra-role behaviors (Van Dyne, Cummings \& Parks, 1995; Van Dyne \& LePine, 1998). There is a long tradition of research dedicated to assessing these behaviors, which are associated with organizational citizenship (Budd et al., 2010; Cantal, Borges-Andrade \& Porto, 2015). Among the various possibilities for expressing these behaviors, we highlight a class that is called "prosocial voice".

Prosocial voice can be understood as a proactive and positively oriented verbal behavior that the worker emits with the intent of promoting some kind of transformation that benefits the group or organization (Botero \& Van Dyne, 2009; Brinsfield, Edwards \& Greenberg, 2009; Islam \& Zyphur, 2005; Morrison, 2011; Morrison, 2014; Nikolaou, Vakola \& Bourantas, 2008; Rusbult, Farrell, Rogers \& Mainous III, 1988; Van Dyne, Ang \& Botero, 2003; Van Dyne \& LePine, 1998). It is therefore a challenging behavior intended to change the status quo, the traditional patterns of how things are done in the organization, facilitating the development of tasks from a future-oriented perspective (LePine \& Van Dyne, 1998; Van Dyne \& LePine, 1998). It thus takes on a promotional character (encouraging something to happen) rather than a reproachful one (encouraging something to cease) (LePine \& Van Dyne, 1998; Van Dyne et al., 1995).

In this sense, the prosocial voice differs from behavior that involves a simple complaint or criticism or even an accusation, by bringing up alternatives, 
thoughts, and suggestions on how the situation can be changed for the better (Brinsfield et al., 2009; LePine \& Van Dyne, 1998; Van Dyne et al., 1995; Van Dyne \& LePine, 1998). Other relevant attributes that characterize the phenomenon relate to the fact that it must be emitted voluntarily by the worker, in oral or written form, encompassing diverse content, which may vary among ideas on how to do things differently and data about serious problems at work, as long as it is directed to someone in the organization capable of taking action based on the information received (Bastos, Carneiro \& Santedicola, 2018; Botero \& Van Dyne, 2009; Morrison, 2011). It is worth mentioning that "promotive voice", "constructive voice" and "organizational citizenship behavior voice" are other terminologies that express similar content but not the same as prosocial voice (Maynes \& Podsakoff, 2014).

Organizations tend to perform better when workers share their ideas and concerns, as information on problems facilitates their correction, and new inputs can also foster advantage in terms of business opportunities, to the extent that diverse opinions, when shared, tend to enrich decision-making processes (Botero \& Van Dyne, 2009; Budd et al., 2010; LePine \& Van Dyne, 1998; Nemeth, Connell, Rogers \& Brown 2001). However, for individuals to be motivated to express themselves and share their thoughts with the organization, there must be a favorable environment for this (Knoll et al., 2016).

Anchored in the positive psychology movement (Seligman \& Csikszentmihalyi, 2000), the abundance mindset has been gaining ground in the management field and can be an interesting alternative to guide the creation and maintenance of healthier organizational environments more conducive to worker participation. This perspective argues that good organizational results depend on a premise of mutual gains between individual and organization. Thus, the organization should be concerned not only with identifying and correcting problems as they arise, but should also focus on investing in the potential of its employees, stimulating their development and their well-being (Demo \& Paschoal, 2016; Rodríguez-Carvajal, Moreno-Jiménez, Rivas-Hermosilla, Álvarez-Bejarano \& Sanz-Vergel, 2010). When workers feel good about their work, perceiving it as a source of meaning and positive rewards, there is a greater tendency for them to engage in collaborative behaviors, on behalf of the context in which this work develops, being more vigilant on issues that can be improved (LePine \& Van Dyne, 1998).

Although the prosocial voice behavior of the worker has a great potential to help drive positive changes in the organization, in the state of the art in Brazil, little attention has been given to this construct, which points to a great mismatch between the domestic and the international literature on the subject. 
Few publications on the topic are found in Brazil (e.g., Andrade, 2018; Bastos et al., 2018; Bastos, Carneiro, Andrade, Aguiar \& D'Almeida, 2019; D’Almeida, 2016; Nascimento, Laros, Porto \& Moraes, 2016), all quite recent. Among these studies, only that of Rayana Santedicola Andrade (2018) presents information that helps to characterize the expression of PSV behavior among Brazilians. The other studies are dedicated only to the theoretical discussion of the phenomenon (Bastos et al., 2018) or to the validation of measures (Bastos et al., 2019; D'Almeida, 2016; Nascimento et al., 2016). Of these, none is dedicated to investigating the associations between this behavior and how the worker feels about his/her work. It is also worth noting that, even in the abundant international publications about voice, this relationship between the subjective state prompted by work in the individual and the expression of voice has been little explored, indicating that there is a study agenda yet to be inaugurated in the field.

Given the above, aiming to contribute to reduce these gaps in the literature, this study has two main objectives. Initially, in an exploratory proposal, the aim is to describe how prosocial voice behaviors are manifested in different Brazilian workers by examining their socio-occupational characteristics, providing more information on how this phenomenon is delineated among them. Then the intent is to broaden the knowledge about the antecedents of voice, by analyzing the predictive power that well-being at work (WBW) has on prosocial voice (PSV) behaviors of the worker.

\section{THEORETICAL FOUNDATION}

In the international literature, voice behavior in organizations began to be investigated in the 1970s, based on Albert Hirschman's seminal studies, which postulated, in his EVL (exit-voice-loyalty) model, that voice was an alternative response of workers to dissatisfaction with something related to the organization: although they could discontinue their relationship with the organization by leaving it (exit), they choose to continue, attempting to complain that they do not agree in order to try to bring about some change (voice), thus demonstrating their loyalty (Brinsfield et al., 2009; Budd et al., 2010; Gorden, 1988; Knoll et al., 2016; Rusbult et al., 1988). It was not long before a research tradition began in the field of employment relations, which considered that the voice of the employees via unions could channel discontent and reduce exit, thus improving productivity (Barry \& Wilkinson, 2016; Gorden, 1988; Kaufman, 2015). Over time, the concept of voice in organizations has expanded to other fields of study and has been redefined to encompass a greater variety of worker verbal communication behaviors that consider diverse characteristics (indi- 
vidual $\mathrm{x}$ collective, active $\mathrm{x}$ passive, constructive vs. destructive, among others) (Gorden, 1988).

During these almost fifty years of scientific production on this phenomenon, various theoretical-conceptual models have emerged, seeking to clarify and differentiate the types of voice that can be emitted by the worker in the organization context (Brinsfield et al., 2009). From the 1990s onwards, in the field of organizational behavior, interest began to fall more intensely on voice not as just a response to dissatisfaction, but rather as a form of extra-role behavior, of a prosocial nature (Brinsfield et al., 2009; Van Dyne \& LePine, 1998), for being characterized as a communication of ideas, suggestions, or opinions whose purpose is to collaborate with the organization and with the workgroup to which the individual belongs, rather than simply criticize.

This type of voice is consistent with the list of behaviors associated with organizational citizenship, but is distinguished from other behaviors more traditionally studied in this field, such as helping behavior (which would represent a more passive form of cooperation), being delineated in fact as a distinct category of prosocial behaviors (Botero \& Van Dyne, 2009; Van Dyne \& LePine, 1998). It is on this class of behaviors, called the prosocial voice (Bastos et al., 2018; Van Dyne et al., 2003; Van Dyne \& LePine, 1998), on which this research elaborates, since, of all the types of voice, this is the one that most clearly has the potential to create positive effects both for the organization and for the workers who emit it.

There are authors who discuss the adequacy of this nomenclature to represent the phenomenon, suggesting that naming this voice behavior pro-management would be more appropriate, given that, by definition, the communication of information should generate benefits for the organization, but this does not necessarily mean generating benefits for the workers as a whole (Barry \& Wilkinson, 2016). Although in the worker-organization relationship, voice behavior may be more contributory to the organization than to the individual, the organizations are social units, which justifies, in the present work, employing the term most widely used in the international literature: prosocial voice (PSV).

As far as PSV is concerned, those who speak do so because they want to benefit the organization or workgroup to which they belong, even if this means confronting opposing ideas and creating some discomfort in the relationship between the parties communicating (LePine \& Van Dyne, 1998; LePine \& Van Dyne, 2001). This happens because PSV is oriented toward change and has a challenging, non-conforming character (LePine \& Van Dyne, 1998; LePine \& Van Dyne, 2001; Van Dyne \& LePine, 1998). In this way, what is said, questioned, or suggested can displease those who hear it, when change is not desired. None- 
theless, Linn Van Dyne and Jeffrey LePine (1998) found that those workers who exhibit more PSV behavior are also better rated by their supervisors in terms of performance, even though this behavior is considered extra-role.

According to Van Dyne et al. (1995) and Elizabeth Morrison (2014), the latent opportunities for verbal expression are accompanied by a number of individual factors (e.g., emotions, attitudes, perceptions about the work and the organization) and contextual ones (e.g., leader's behavior, social support) that can act as motivators or inhibitors of the worker's voice. Among the individual factors, the subjective experience that involves both affective and cognitive aspects associated with the work, represented by the work-related well-being construct, is of particular interest here.

Work-related well-being is a phenomenon that has received increasing attention from the scientific community and from the management of organizations. It, also, began to be scientifically studied about five decades ago, based on the initial contributions of Peter Warr (1978), who argued the importance of assessing well-being in relation to specific contexts, especially that of work. At first, work-related well-being research began slowly, gaining greater intensity after the 2000s, driven by the positive psychology movement (Carneiro \& Fernandes, 2015; Paschoal, et al., 2013). Since then, multiple conceptualizations have emerged intending to account for the meaning of this phenomenon.

In this study, well-being at work (WBW) is defined as a positive subjective state of workers, due to the prevalence of the occurrence of positive affects over the occurrence of negative affects, as well as the experience of growth and fulfillment opportunities through their work, which should allow them to express their potentialities (Paschoal \& Tamayo, 2008; Warr, 2007). This concept signifies the combining of two classical theoretical-philosophical perspectives in understanding this phenomenon: the hedonic, which focuses on the pleasure resulting from the satisfaction of needs, and the eudaimonic, which focuses on the process of seeking the development individuals in support of their optimal level of functioning, of their best version (Waterman, 2007).

The main theoretical models of PSV include affective states as important predictors of this behavior, assuming that when experiencing positive affective states, people are more likely to act to maintain the good feelings (Van Dyne et al., 1995; LePine \& Van Dyne, 1998), thus engaging in PSV behaviors that will help the organization survive and allow the work to continue being a source of pleasure and individual development (LePine \& Van Dyne, 1998). With a more specific look at WBW's eudaimonic basis, it is also considered that PSV can be seen as a result of the expression of workers' potential, who see in their work different ways of doing things, communicating their innovative ideas, generat-

http://quadernsdepsicologia.cat 
ing a more efficient process, and at the same time, personal achievement because they are contributing to the group.

The relationship between WBW and voice behavior in organizations has not been directly assessed in any published study, however, in the theoretical review conducted by Brian Klaas, Julie Olson-Buchanan and Anna-Katherine Ward (2011) on the determinants of different types of voice, some elements taken as correlates or indicators of work-related well-being appear in the composition of predictors of prosocial voice. Among these elements is the perception of growth opportunities, which is directly associated with the possibility for individuals to develop in their work, being a factor corresponding to the eudaimonic conception of well-being. A good relationship with management is also positively associated with the manifestation of informal voice for collaborative purposes. This element is understood by authors such as Marina Dessen and Maria das Graças Paz (2010) and Cleide Silva and Maria Cristina Ferreira (2013) as one of the indicators that represent the construct of work-related well-being. Likewise, the review points out that job satisfaction, understood by some authors such as Mirlene Siqueira and Valquíria Padovam (2008) as a representative of the hedonic conception of well-being, is also capable of increasing the likelihood that workers will express their own prosocial voice.

Thus, although there is no prior empirical evidence that clearly attests to the role that well-being at work (as understood here) plays in the display of PSV behaviors, it is considered that the preliminary data presented along with the theoretical justification suggest that WBW may be an important antecedent of PSV.

\section{METHODOLOGICAL DESIGN}

This study is characterized as quantitative, extensive, and cross-sectional.

Participants: This study included 360 workers from different segments, occupations, and levels of education, who had at least 3 months employment with the organization. This time, according to the Decree of Law No. 229 of 1967 pertaining to the Brazilian Consolidation of Labor Laws $(C L T)$, constitutes the trial period, in which the worker is still adapting to the company and his/her permanence is still unstable. Although not all workers in this study are linked to their organizations through the $C L T$, it is understood that this condition serves as a control, since it presupposes a reasonable time for workers to know and adapt minimally to their work activities and the organization as a whole in which they develop their work, thus allowing a more accurate assessment of 
the phenomena evaluated here, namely, the well-being of the workers and their commitment to the organization.

In terms of participant age, the range was 19 to 66 years $(M=35.80 ; S D=10.64)$. Most of the participants were female $(69.6 \%)$, and had already completed some graduate studies $(51.7 \%)$, being specialization, masters, or doctorate, although workers with a lower level of education also participated, such as elementary and secondary (9.1\%). Regarding professional data, most of the workers performed activities related to the services area (41.2\%), being mainly concentrated in private organizations (57.8\%), but also in public organizations $(32.7 \%)$, and from the third sector $(9.5 \%)$. Only $20.5 \%$ of the participants held senior positions at the time they answered the survey and $58.6 \%$ of the sample received up to 4 times the minimum wage.

Data collection instrument: For this study, an extract was made from a larger study, and the version used consisted of 3 (three) parts:

(1) Sociodemographic and occupational information: questions that recollect the trajectory of each worker, their social origin, family context, entry into the working world. This included data on gender, age, educational background, work experience.

(2) Well-being at Work Scale: proposed and validated by Tatiane Paschoal and Álvaro Tamayo (2008), consisting of 30 items distributed into three factors: "positive affect" ( 9 items, $a=0.93$ ), "negative affect" ( 12 items, $a=0.91$ ), and "expressiveness/achievement at work" ( 9 items, $a=0.88$ ). The items had to be evaluated based on 5-level response options, with an intensity scale for the first two factors cited being (1- Not at all; 2- Not much; 3-Moderately; 4- Quite a lot; 5- Extremely) and an agreement scale for the last factor (1- Totally disagree; 2- Partially disagree; 3- Do not agree or disagree; 4- Partially agree; 5Totally agree). Examples of items include: "happy" for PA, "angry" for NA, and "I achieve my potential" for E/A.

(3) Prosocial voice in Organizations Scale: developed, adapted, and validated to Brazilian context by Antônio Virgílio Bastos et al. (2019), based on the conception of Van Dyne et al. (2003). The Likert scale is single-factor in nature (8 items, $a=0.91$ ), with 5 response options that consider the frequency of emitted voice behavior (1- Never; 2- Rarely; 3- Sometimes; 4- Often; 5- Always). Included as an example of the item: "I make suggestions about how to do things more effectively at work".

Data collection procedures: In order to facilitate access to the desired number and variety of participants, data collection took place through a selfadministered questionnaire in digital form from the SurveyMonkey platform. A 
"snowball" type of convenience sampling was used, in which the researcher's contact network was used as the trigger base for invitations to participate in the research. Those invited were asked to forward the invitation to others in their contact networks who could meet the requested prerequisites to participate in the survey.

Data analysis procedures: Data were tabulated using SPSS (Statistical Package for Social Sciences) 17.0 software, through which the following analyses were done: adequacy and normality of the sample, descriptive statistics, differences between groups ( $t$-test and ANOVA), Pearson's correlation, and multiple linear regression. Exploratory factor analyses (EFA) through SPSS and confirmatory factor analyses (CFA) through AMOS were also done to ensure the fit of the scales to the sample, as indicated by Juliane Borsa and Mariana Seize (2017). In the case of the WBW scale, it was necessary to exclude three items in fitting the instrument to the sample, leaving the final instrument used on this study with 27 items. Whereas the PSV scale kept its original configuration. The psychometric data from the scales after fitting to the sample can be seen in Table 1.

\begin{tabular}{|c|c|c|c|c|}
\hline Scale & $\begin{array}{l}\text { Total explained } \\
\text { variance }\end{array}$ & Factor structure & $\begin{array}{l}\text { Composition of the } \\
\text { factors }\end{array}$ & Factor loadings \\
\hline \multirow{3}{*}{ WBW } & \multirow{3}{*}{$62 \%$} & Positive affects & 8 items, $a=.939$ & .642 to .928 \\
\hline & & Negative affects & 10 items, $a=.910$ & .590 to .833 \\
\hline & & $\begin{array}{c}\text { Expressiveness / Achieve- } \\
\text { ment }\end{array}$ & 9 items, $a=.892$ & .404 to .833 \\
\hline PSV & $63 \%$ & Single-factor & 8 items, $a=.915$ & .470 to .640 \\
\hline
\end{tabular}

Table 1. Psychometric data from the scales used in the study

\section{RESULTS AND DISCUSSION}

Considering that only few Brazilian studies dedicated to the investigation of workers' prosocial voice behaviors were found, with three of them focused on the construction and validation of the instrument, the present study first conducted exploratory, descriptive, and intergroup differences analyses for the purpose of gathering more information about how this phenomenon is manifested in Brazilian professionals.

It was found that the overall mean for PSV of the participants in this study was $3.95(\mathrm{SD}=0.72)$. Considering the scale's range from 1 to 5 , it can be inferred that this was a relatively high mean, indicating that, in general, the study participants estimate that they often express constructive ideas, opinions, and suggestions to the organization. Although high, this value is consistent with 
those found in previous research using the same instrument in Brazil (Andrade, 2018) $(M=3.85, S D=0.78)$ and with a similar instrument in Argentina (Omar, 2010) $(M=3.95, S D=0.73)$. It is important that this value is carefully evaluated, since, as a behavior expected by the organization, the PSV self-assessment may suffer the effect of social desirability, even though the anonymity of the participants was safeguarded.

Interestingly, on comparing how PSV is manifested in different groups of workers (Table 2), it is evident that professionals who hold management positions present levels of PSV expression $(M=4.26, S D=0.48)$ significantly higher $(t(166)=5.17, p>0.01)$ than that of professionals who do not hold management positions $(M=3.88, S D=0.75)$. This result was expected because, in general, professionals in various levels of management have more autonomy and decision-making power within the organization, in addition to being more pressured to actively contribute to the improvement of various organizational processes, so it is logical that they issue more ideas and suggestions than those workers who are not in this position. The difference in the pattern of prosocial voice manifestation between managers and non-managers was also identified by Andrade (2018). In the same direction, Gazi Islam and Michael Zyphur (2005) showed that workers with higher power voice their opinions to a greater extent than workers with less power. LePine and Van Dyne (1998) went even further, observing the increase in PSV manifestation as the worker's hierarchical level / status rose.

\begin{tabular}{llcccc}
\hline $\begin{array}{l}\text { Socio-occupational } \\
\text { variables }\end{array}$ & Category & $N$ & $M(S D)$ & $t / F$ & $p$ \\
\hline Sex & Male & 71 & $3.93(0.71)$ & -0.341 & 0.730 \\
& Female & 277 & $3.96(0.73)$ & & \\
\hline Management posi- & Yes & 109 & $4.26(0.48)$ & 5.178 & 0.000 \\
tion & No & 250 & $3.88(0.75)$ & & \\
\hline \multirow{4}{*}{ Organization type } & Public & 177 & $3.89(0.67)$ & & \\
& Private & 207 & $3.98(0.75)$ & 0.556 & 0.574 \\
& Third Sector & 34 & $3.93(0.70)$ & & \\
\hline \multirow{4}{*}{ Organization size } & Micro & 61 & $3.97(0.72)$ & & \\
& Small & 41 & $4.07(0.78)$ & & \\
& Medium & 53 & $4.07(0.77)$ & & 0.262 \\
& Large & 202 & $3.89(0.69)$ & & \\
\hline
\end{tabular}

Table 2. Comparison of the manifestation of prosocial voice (PSV) behavior in different socio-occupational groups 
As regards the evaluation of the organizational level variables, no significant differences were found in the voice emission by workers from organizations of different types $(F=0.556, p=0.574)$ and sizes $(F=1.338, p=0.262)$ (Table 2$)$. The first comparison had already been made by Andrade (2018), who also did not identify differences in the frequency of PSV between workers employed in public and private organizations. These data suggest that Brazilian workers express their ideas and opinions in a similar way in different organizations.

There was also no significant difference $(t(211)=-0.34, p=0.730)$ in the mean PSV emission between men $(M=3.93, S D=0.71)$ and women $(M=3.96, S D=0.73)$ (according to Andrade, 2018; Burris, Detert \& Romney, 2013), which shows that male and female Brazilian workers share suggestions about the work in the organization where they are employed with similar frequency. It should be noted that in some international studies, gender appears as a variable associated with how much PSV will be emitted (e.g., LePine \& Van Dyne, 1998; Omar, 2010). Although this association has proven to be of weak intensity (e.g., LePine \& Van Dyne, 1998; Omar, 2010), this indicates a possible cultural influence on the results of gender vs. PSV.

Furthermore, correlation analyses (Table 3 ) indicate that age is positively associated with the emission of voice behaviors, which means that the older the workers, the more frequently they communicate constructive information for the organization, although the magnitude of this association is weak $(r=0.163$, $p<0.01$ ), in accordance with the result found by Andrade (2018). Likewise, PSV seems to be more frequent, the higher the worker's compensation $(r=0.233$, $p<0.01)$ and the higher his/her level of education $(r=0.225, p<0.01)$. According

\begin{tabular}{|c|c|c|c|}
\hline Variables & M & SD & $r$ \\
\hline 1. PSV & 3.95 & 0.72 & - \\
\hline 2. Age (in years) & 35.8 & 10.65 & $0.163^{* *}$ \\
\hline 3. Education & 3.61 & 0.92 & $0.225^{* *}$ \\
\hline $\begin{array}{l}\text { 4. Compensation (multiples of minimum } \\
\text { wage) }\end{array}$ & 3.97 & 1.91 & $0.233^{* *}$ \\
\hline 5. Time in the organization (in years) & 6.88 & 7.92 & 0.074 \\
\hline \multicolumn{4}{|c|}{${ }^{* *} p<0.01$} \\
\hline \multicolumn{4}{|c|}{$\begin{array}{l}\text { Note: Education and compensation were evaluated as ordinal variables. Ed- } \\
\text { ucation: } 1 \text { - Up to elementary school; } 2 \text {-High school; } 3 \text {-College level (incom- } \\
\text { plete and complete); } 4 \text {-Graduate level, latu sensu } 5 \text { - Graduate level, strictu } \\
\text { sensu. Compensation (in multiples of minimum wage): } 1 \text { - Up to } 1 ; 2-\text { More } \\
\text { than } 1 \text { up to } 2 ; 3 \text { - More than } 2 \text { up to } 3 ; 4 \text { - More than } 3 \text { up to } 4 ; 5 \text { - More than } 4 \\
\text { up to } 5 ; 6-\text { More than } 5 \text { up to } 10 ; 7-\text { More than } 10 \text { up to } 20 ; 8 \text { - Over } 20 \text {. Time } \\
\text { in the organization was evaluated in years. }\end{array}$} \\
\hline
\end{tabular}

Table 3. Correlation matrix between PSV and socio-occupational variables 
to LePine and Van Dyne (1998), workers with higher education levels are probably technically better prepared to recognize problems and opportunities for improvement, as well as to offer a wider range of possible ideas or suggestions for the issues identified.

On the other hand, time working in the organization did not present a significant relationship with the frequency with which workers use their PSV $(r=0.074, p=0.163)$, contrary to previous study findings (Andrade, 2018), which had identified that time with the company was positively associated, though at a low magnitude, with the emission of voice behaviors. This discrepancy of results may be related to sample peculiarities or even to the measurement used for calibrating time.

Table 4 shows a comparative synthesis between the results of the association of socio-occupational variables with PSV behavior in the present study and in the only study found that evaluates this phenomenon in Brazilian workers.

\begin{tabular}{lccc}
\hline Variable level & $\begin{array}{c}\text { Socio-occupational } \\
\text { variables }\end{array}$ & $\begin{array}{c}\text { This } \\
\text { study }\end{array}$ & Andrade (2018) \\
\hline \multirow{3}{*}{ Individual } & Gender & No & No \\
& Age & Yes & Yes \\
& Education & Yes & Yes \\
\hline \multirow{2}{*}{ Occupational } & Time in the organization & No & Yes \\
& Compensation* & Yes & - \\
\hline \multirow{2}{*}{ Organizational } & Management position or not & Yes & Yes \\
& Organization type & No & No \\
\hline
\end{tabular}

Note: The variables compensation and organization size were not evaluated in Andrade's study (2018).

Table 4. Interactions of socio-occupational variables with prosocial voice (PSV) behavior in Brazilian workers

Summarizing, it can be reported that in this study, the older, better educated, better paid workers in management positions express their ideas, suggestions, and recommendations in order to bring about positive changes in the work context.

In addition to the analyses that sought to evaluate the manifestation of PSV among different socio-occupational groups, we pursued to investigate the correlations found between PSV and WBW, both in their general measure and in relation to their subfactors, individually (Table 5 ). The results obtained indi- 
cate that well-being and voice behavior are associated with moderate intensity $(r=0.344, p<0.01)$, corroborating the expectation generated by previous studies that verified the association between PSV and indicators and/or constructs correlated to WBW as adopted in this study (Klaas et al., 2011).

Upon analyzing the association between the factors of WBW, independently, and PSV, we identified that there is no significant relation-

\begin{tabular}{lccc}
\hline $\begin{array}{l}\text { Different levels of } \\
\text { WBW } \\
\text { measurement }\end{array}$ & M & SD & PSV \\
\hline $\begin{array}{l}\text { WBW overall meas- } \\
\text { ure }\end{array}$ & 3.58 & 0.65 & $0.346^{* *}$ \\
$\begin{array}{l}\text { Prevalence of PA } \\
\text { over NA }\end{array}$ & 3.33 & 0.75 & $0.216^{* *}$ \\
$\begin{array}{l}\text { Negative affects } \\
\text { Positive affects }\end{array}$ & 2.38 & 0.85 & -0.051 \\
$\begin{array}{l}\text { Expressiveness / } \\
\text { Achievement }\end{array}$ & 3.06 & 0.90 & $0.311^{* *}$ \\
\hline$* *$ p $<0.01$ & 0.71 & $0.407^{* *}$ \\
\hline
\end{tabular}

Table 5. Correlations between PSV and WBW ship between the experience of negative affect and the expression of voice behaviors $(r=-0.051, p=0.331)$. This demonstrates that this factor should not be assessed in isolation, since alone it cannot be considered as an appropriate representative of WBW. On the other hand, according to the results found, the greater the prevalence of positive affects $(r=0.216, p<0.01)$ and the opportunities for achievement and expression of one's own potential through work $(r=0.407, p<0.01)$, the greater the frequency of expression of PSV. Thus, the strength of association of PSV with the eudaimonic base of WBW was greater than with the hedonic base, in agreement with previous studies that had already pointed out that the impact of eudaimonism on extra-role behaviors is more significant than that of hedonism (Turban \& Yan, 2016), since this first base reflects the well-being that is the result of a process that seeks change and growth.

Based on the determination that WBW and some socio-occupational variables were positively associated with PSV emission, we sought to examine, through multiple regression analysis, which elements best explain the occurrence of PSV. The stepwise extraction method was used, seeing that the intention was to check which antecedent variables would remain in the model (Field, 2009). Results are shown in Table 6.

In the first model, the results suggested only the maintenance of WBW as the strongest antecedent variable of PSV $\left(R^{2}=0.115, B=0.313, p<.001\right)$, being able to explain around $11 \%$ of the variance of PSV. In the second and last model, age, compensation, and position of the worker in the organization (management position or not) were excluded, demonstrating that the greatest explanatory force of PSV in relation to the variables analyzed is concentrated on how much the individual feels good about their work $(B=0.313)$ and on how much 


\begin{tabular}{|c|c|c|c|c|c|}
\hline \multicolumn{2}{|c|}{ Summary of model 1} & $\begin{array}{c}\mathbf{R} \\
.339 \\
\end{array}$ & $\begin{array}{l}\mathbf{R}^{2} \\
.115 \\
\end{array}$ & $\begin{array}{c}\mathrm{R}^{2} \text { Adjusted } \\
.112 \\
\end{array}$ & $\begin{array}{l}\text { Sig. } \\
.000\end{array}$ \\
\hline Antecedent variable & Criterion variable & B & Beta & $\mathbf{t}$ & Sig. \\
\hline WBW & PSV & 0.376 & 0.339 & 6.703 & .000 \\
\hline \multirow{2}{*}{\multicolumn{2}{|c|}{ Summary of model 2}} & $\mathbf{R}$ & $\mathbf{R}^{2}$ & $\mathbf{R}^{2}$ Adjusted & Sig. \\
\hline & & .394 & .155 & .150 & .000 \\
\hline Antecedent variables & Criterion variable & B & Beta & $\mathbf{t}$ & Sig. \\
\hline WBW & PSV & 0.347 & 0.313 & 6.276 & .000 \\
\hline Education & & 0.158 & 0.202 & 4.038 & .000 \\
\hline
\end{tabular}

Table 6. Linear Regression with PSV antecedents

one has achieved in terms of education $(B=0.202)$. Together, these variables (WBW and education) explain about $16 \%$ of the variance in PSV expression $\left(R^{2}=0.155, p<.001\right)$ (Table 6).

These findings support the assumption that work environments that provide healthier, more positive experiences tend to be environments more conducive for workers to share their ideas, suggestions, and opinions on how to generate constructive transformations that contribute to achieving good organizational results. In addition, they demonstrate the importance of the academic training of professionals who, as they grow, better prepares them to identify and propose points of improvement in their work context.

\section{FINAL CONSIDERATIONS}

This research provided insights to understand how one of the discretionary behaviors that organizations expect to be emitted by their employees, PSV, is manifested in Brazilian workers, given that, until this time only one study was found that published this type of information. In order to characterize this phenomenon in Brazil, in a descriptive-exploratory perspective, it could be seen that some occupational variables, such as compensation and the type of position held in the organization (management or not) as well as individual variables, such as age and education, affect the frequency of PSV emission.

In this same direction, it contributed in the sense of providing data about the actual pattern of association between the subjective state of the individual in relation to his/her work (WBW) and PSV, inaugurating an agenda of empirical studies not only in the Brazilian context, but also internationally. It was possible to identify that, as already predicted in theory, the better workers feel in relation to their work, the more likely they are to engage in PSV behaviors, aiming to intentionally share suggestions, ideas, or proposals that contribute to 
the good performance of the organization. Being the first identified study that evaluates the relationship between these two variables, it is understood that the results presented here should be interpreted with caution, but also as a stimulus for further studies to be developed in order to collect more evidence for understanding the relationship between these two phenomena.

Together, WBW and the socio-occupational variable education of the worker were able to explain about $16 \%$ of the variance of PSV. Although significant, this result demonstrates that there is still a wide range of PSV behavior that has not been explained, and it is important to continue with the development of research that considers the introduction of new variables as antecedents. PSV is a complex behavior that may be influenced by phenomena that act at different levels - individual, group and organizational. Therefore, it would be valuable if multilevel research could be conducted to explore combined antecedents of each of those levels.

Considering the possible impact of social desirability on workers' selfassessment of how much they express ideas, suggestions, and collaborative information to the organization, it is interesting that future studies should focus on investigating this phenomenon based on a combination of self- and heteroassessment instruments. People who play different roles in an organization may view the same behavior differently, as they have different expectations about this, or even a selective attention with respect to which aspects of the situation are grasped (Van Dyne et al., 1995; Van Dyne \& LePine, 1998). Thus, it is considered that the sole criterion of self-report may be a limitation of the present research, as it singled out the workers' view of their voice, disregarding the view of people in other roles, such as co-workers and managers.

\section{REFERENCES}

Andrade, Rayana Santedicola (2018). Comportamentos de voz e silêncio nas organizações de trabalho: explorando seus preditores entre organizações e trabalhadores brasileiros. Unpublished Doctoral thesis. Universidade Federal da Bahia-BA

Barry, Michael \& Wilkinson, Adrian (2016). Pro-Social or Pro-Management? A Critique of the Conception of Employee Voice as a Pro-Social Behavior within Organizational Behavior. British Journal of Industrial Relations, 54(2), 261-284.

https://doi.org/10.1111/bjir.12114

Bastos, Antônio Virgílio Bittencourt; Carneiro, Laila Leite \& Santedicola, Rayana (2018). Comprometimento e voz pró-social nas organizações e no trabalho à luz da psicologia positiva. In: Ana Claudia S. Vazquez \& Claudio Simon Hutz (Orgs.), Aplicações da psicologia positiva: Trabalho e organizações. (pp. 201-220). São Paulo: Hogrefe 
Bastos, Antônio Virgílio Bittencourt; Carneiro, Laila Leite; Andrade, Rayana Santedicola; Aguiar, Carolina Vila Nova \& D’Almeida, Adriana Souza (2019). Escala de voz nas organizações (EVO). In: Claudio Simon Hutz, Denise Ruschel Bandeira, Clarissa Marceli Trentini, Ana Claudia S. Vazquez (Orgs.). Avaliação Psicológica no Contexto Organizacional e do Trabalho (pp. 257-267). Porto Alegre: Artmed

Botero, Isabel C. \& Van Dyne, Linn (2009). Employee Voice Behavior. Management Communication Quarterly, 23(1), 84-104.

https://doi.org/10.1177/0893318909335415

Borsa, Juliane Callegaro \& Seize, Mariana de Miranda (2017). Construção e adaptação de instrumentos psicológicos: dois caminhos possíveis. In: Bruno Figueiredo Damásio \& Juliane Callegaro Borsa (Orgs.), Manual de desenvolvimento de instrumentos psicológicos (pp. 15-37). São Paulo: Vetor

Brinsfield, Chad T.; Edwards, Marissa S. \& Greenberg, Jerald (2009). Voice and silence in organizations: historical review and current conceptualizations. In: Jerald Greenberg, Marissa S. Edwards. (Orgs.), Voice and Silence in Organizations (pp. 3-33). United Kingdom: Emerald.

Budd, John W.; Gollan, Paul J. \& Wilkinson, Adrian (2010). New approaches to employee voice and participation in organizations. Human Relations, 63(3), 303-310. https: / / doi.org/10.1177/0018726709348938

Burris, Ethan R.; Detert, James R. \& Romney, Alexander C. (2013). Speaking up vs. being heard: the disagreement around and outcomes of employee voice. Organization Science, 24(1), 22-38. https://doi.org/10.1287/orsc.1110.0732

Cantal, Clara; Borges-Andrade, Jairo E. \& Porto, Juliana B. (2015). Cooperação, comportamentos proativos ou simplesmente cidadania organizacional? Uma revisão da produção nacional na área. Revista Psicologia: Organizações e Trabalho, 15(3), 286297. https: //doi.org/10.17652/rpot/2015.3.331

Carneiro, Laila Leite \& Fernandes, Sônia Regina Pereira (2015). Bem-estar pessoal nas organizações e lócus de controle no trabalho. Revista Psicologia: Organizações e Trabalho, 15(3), 257-270. https://doi.org/10.17652/rpot/2015.3.599

D’Almeida, Adriana Souza (2016). Construção e validação de uma medida brasileira de voz e silêncio nas organizações. Unpublished Masters dissertation, Universidade Federal da Bahia

Decreto de Lei $\mathrm{n}^{\circ} 229$ de 28 de fevereiro de 1967. (1967, 28 de fevereiro). Consolidação das Leis do Trabalho. Diário Oficial da União, Seção 1. Recuperado de http://www.planalto.gov.br/ccivil_03/decreto-lei/Del0229.htm\#art443§2

Demo, Gisela, \& Paschoal, Tatiane (2016). Well-Being at Work Scale: Exploratory and confirmatory validation in the USA. Paidéia (Ribeirão Preto), 26(63), 35-43. https: / / doi.org/10.1590/1982-43272663201605

Dessen, Marina Campos \& Paz, Maria das Graças Torres (2010). Validação do instrumento de indicadores de bem-estar nas organizações. Psicologia em Estudo, 15(2), 409-418. https://doi.org/10.1590/s1413-73722010000200020

Field, Andy (2009). Descobrindo a estatística usando o SPSS. Porto Alegre: Artmed.

Gorden, William I. (1988). Range of employee voice. Employee Responsibilities and Rights Journal, 1(4), 283-299. https://doi.org/10.1007/BF01556937 
Islam, Gazi, \& Zyphur, Michael J. (2005). Power, voice, and hierarchy: exploring the antecedents of speaking up in groups. Group Dynamics: Theory, Research, and Practice, 9(2), 93-103. https:// doi.org/10.1037/1089-2699.9.2.93

Kaufman, Bruce E. (2015). Theorising determinants of employee voice: An integrative model across disciplines and levels of analysis. Human Resource Management Journal, 25(1), 19-40. https://doi.org/10.1111/1748-8583.12056

Klaas, Brian S.; Olson-buchanan, Julie B. \& Ward, Anna-Katherine (2011). The Determinants of Alternative Forms of Workplace Voice: An Integrative Perspective. Journal of Management, 38(1), 314-345. https://doi.org/10.1177/0149206311423823

Knoll, Michael; Wegge, Jürgen; Unterrainer, Christine; Silva, Silvia \& Jønsson, Thomas (2016). Is our knowledge of voice and silence in organizations growing? Building bridges and (re)discovering opportunities. German Journal of Human Resource Management, 30(3-4), 161-194. https://doi.org/10.1177/2397002216649857

LePine, Jeffrey A. \& Van Dyne, Linn (1998). Predicting voice behavior in work groups. Journal of Applied Psychology, 83(6), 853-868. https://doi.org/10.1037/0021$\underline{9010.83 .6 .853}$

LePine, Jeffrey A. \& Van Dyne, Linn (2001). Voice and cooperative behavior as contrasting forms of contextual performance: Evidence of differential relationships with big five personality characteristics and cognitive ability. Journal of Applied Psychology, 86(2), 326-336. https://doi.org/10.1037/0021-9010.86.2.326

Maynes, Timothy D., \& Podsakoff, Philip M. (2014). Speaking more broadly: an examination of the nature, antecedents, and consequences of an expanded set of employee voice behaviors. The Journal of Applied Psychology, 99(1), 87-112.

https://doi.org/10.1037/a0034284

Morrison, Elizabeth W. (2011). Employee voice behavior: Integration and directions for future research. Academy of Management Annals, 5(1), 373-412.

https: / / doi.org/10.1080/19416520.2011.574506

Morrison, Elizabeth W. (2014). Employee voice and silence. Annual Review of Organizational Psychology, 1(7), 1-25. https://doi.org/10.1146/annurev-orgpsych-031413$\underline{091328}$

Nascimento, Thainá Tavares; Laros, Jacob Arie; Porto, Juliana Barreiros \& Moraes, Melissa Machado de (2016). Assumir o comando no trabalho: Evidências de validade da versão brasileira da escala. Psicologia: Teoria e Pesquisa, 32(3), 1-9. https://doi.org/10.15900102-3772e323212

Nemeth, Charlan Jeanne; Connell, Joanie B.; Rogers, John D. \& Brown, Keith S. (2001). Improving decision making by means of dissent. Journal of Applied Social Psychology, 31(1), 48-58. https://doi.org/10.1111/j.1559-1816.2001.tb02481.x

Nikolaou, loannis; Vakola, Maria \& Bourantas, Dimitris (2008). Who speaks up at work? Dispositional influences on employees' voice behavior. Personnel Review, 37(6), 666679. https: //doi.org/10.1108/00483480810906892

Omar, Alicia (2010). Antecedentes y consecuencias de los comportamientos prosociales de voz y silencio. Psicología, Cultura y Sociedad, 10, 249-268.

https://doi.org/10.18682/pd.v10i0.399 
Parker, Sharon K.; Williams, Helen M. \& Turner, Nick (2006). Modeling the antecedents of proactive behavior at work. Journal of Applied Psychology, 91(3), 636-652. https: // doi.org/10.1037/0021-9010.91.3.636

Paschoal, Tatiane; Demo, Gisela; Fogaça, Natasha; Ponte, Valter; Edrei, Laylla; Francischeto, Leela \& Albuquerque, Gabriela (2013). Bem-estar no trabalho: cenário dos estudos brasileiros publicados na primeira década do novo milênio. Proceedings TMS Inc. Conference 2012: Human Resources, Business Ethics e Governance, 2(Special Issue), 384-395.

Paschoal, Tatiane, \& Tamayo, Álvaro (2008). Construção e validação da escala de bemestar no trabalho. Avaliação Psicológica, 7(1), 11-22.

Rodríguez-Carvajal, Raquel; Moreno-Jiménez, Bernardo; Rivas-Hermosilla, Sara; Álvarez-Bejarano, Abraham \& Sanz-Vergel, Ana Isabel (2010). Positive psychology at work: mutual gains for individuals and organizations. Revista de Psicología del trabajo y de las organizaciones, 26(3), 235-253. https://doi.org/10.5093/tr2010v26n3a7

Rusbult, Caryl E.; Farrell, Dan; Rogers, Glen \& Mainous III, Arch G. (1988). Impact of exchange variables on exit, voice, loyalty, and neglect: an integrative model of responses to declining job status satisfaction. Academy of Management Journal, 31(3), 599-627. http:// doi.org/10.2307/256461

Seligman, Martin E. P. \& Csikszentmihalyi, Mihaly (2000). Positive psychology: An introduction. American Psychologist, 55, 5-14. https://doi.org/10.1037//0003066x.55.1.5

Silva, Cleide Aparecida da \& Ferreira, Maria Cristina (2013). Dimensões e Indicadores da Qualidade de Vida e do Bem-Estar no Trabalho. Psicologia: Teoria e Pesquisa, 29(3), 331-339. https: //doi.org/10.1590/S0102-37722013000300011

Siqueira, Mirlene Maria Matias \& Padovam, Valquiria Aparecida Rossi (2008). Bases teóricas de bem-estar subjetivo, bem-estar psicológico e bem-estar no trabalho. Psicologia: Teoria e Pesquisa, 24(2), 201-209. https://doi.org/10.1590/s010237722008000200010

Turban, Daniel B., \& Yan, Wan (2016). Relationship of eudaimonia and hedonia with work outcomes. Journal of Managerial Psychology, 31(6), 1006-1020. https://doi.org/10.1108/JMP-07-2015-0271

Van Dyne, Linn; Ang, Soon \& Botero, Isabel C. (2003). Conceptualizing employee silence and employee voice as multidimensional constructs. Journal of Management Studies, 40(6), 1359-1392. https://doi.org/10.1111/1467-6486.00384

Van Dyne, Linn; Cummings, Larry L. \& Parks, Judi McLean (1995). Extra-role behaviors: In pursuit of construct and definitional clarity (a bridge over muddied waters). Research in Organizational Behavior, 17, 215-285.

Van Dyne, Linn \& LePine, Jeffrey A. (1998). Helping and Voice Extra-Role Behaviors: Evidence of Construct and Predictive Validity. The Academy of Management Journal, 41(1), 108-119. https://doi.org/10.2307/256902

Warr, Peter (1978). A study of psychological well-being. British Journal of Psychology, 69, 111-121. https://doi.org/10.1111/j.2044-8295.1978.tb01638.x

Warr, Peter (2007). Learning about employee happiness. Revista Psicologia Organizações e Trabalho, 7(2), 133-140. 
Waterman, Alan S. (2007). On the importance of distinguishing hedonia and eudaimonia when contemplating the hedonic treadmill. The American Psychologist, 62(6), 612-3. https: // doi.org/10.1037/0003-066X62.6.612

\section{LAILA LEITE CARNEIRO}

Psychologist, PhD in Organizational and Work Psychology, Associate Professor at Federal University of Bahia

laila_carneiro@hotmail.com

https://orcid.org/0000-0001-7183-0501

\section{ANTÔNIO VIRGÍLIO BITTENCOURT BASTOS}

Psychologist, PhD in Organizational and Work Psychology, Full Professor at Federal University of Bahia antoniovirgiliobastos@gmail.com

\section{FORMATO DE CITACIÓN}

Leite Carneiro, Laila \& Bittencourt Bastos, Antônio Virgílio (2020).Work well-being and prosocial behavior in a sample of Brazilian workers. Quaderns de Psicologia, 22(1), e1583. http://dx.doi.org/10.5565/rev/qpsicologia.1583

\section{HISTORIA EDITORIAL}

Recibido: 27-10-2019

$1^{a}$ revisión: 21-01-2020

Aceptado: 21-02-2020

Publicado: $30-04-2020$ 